\title{
11. \\ MARIJA RADIĆ I MIRA KOŠUTIĆ: \\ INTELEKTUALKE U POLITIČKOJ MISIJI
}

\section{Martina Bitunjac}

UDK: 32-05Radić, $M$.

32-05Košutić, $M$

Stručni članak

\begin{abstract}
Sažetak: Marija Radić, rođena Dvořák (1874.-1954.) i njezina kćer Mira (1901.-1988.) imale su značajne uloge u jugoslavenskom odnosno hrvatskom kulturnom i političkom životu. Kao supruga Stjepana Radića, vođe Hrvatske seljačke stranke, Marija Radić osnovala je ženske organizacije HSS-a i borila se zajedno s mužem za prava žena. Atentat na Stjepana Radića, koji je 1928. godine izvršio radikal Puniša Račić, omogućio je glorifikaciju Marije Radić u Nezavisnoj Državi Hrvatskoj kao udovice tobožnjeg „ustaškog mučenika”. Njezina kćerka Mira, udana Košutić, prekinuvši studij nakon očeve smrti, vodila je obiteljsku zagrebačku knjižaru. Za vrijeme rata 1941.-1945. godine, zajedno sa suprugom Augustom Košutićem, podpredsjednikom HSS-a, ilegalno je pripremala poslijeratnu obnovu stranke. Nastojanja su bila uzaludna. Mira Košutić je bila uhićena, a zagrebački skojevci su uništili zagrebačku knjižaru. Ovaj članak sažima političku djelatnost i političku kulturu ove dvije žene, nezaobilazne u hrvatskoj povijesti svog doba.
\end{abstract}

Ključne riječi: Marija Radić, Mira Košutić, Hrvatska seljačka stranka

\section{Politički i društveni rad prije 1941.}

Marija Dvořák, rođena 27. kolovoza 1874. godine u Pragu, po struci učiteljica, upoznala je svoga budućeg supruga, Stjepana Radića, u dvorcu Karlšejn 1894. godine. Poznanstvo s njime omogućilo joj je da upozna i aktere hrvatske opozicijske politike. Njezin je budući suprug već tada bio izbačen sa Sveučilišta u Zagrebu zbog protuugarske agitacije, napose zbog suprotstavljanja politici hrvatskog bana Károlyja Khuen-Héderváryja 1893. godine. Dvije godine kasnije, 1895., nakon sudjelovanja u spaljivanju mađarske zastave na Trgu bana Josipa Jelačića u Zagrebu, počinjenog isti dan kada je car i kralj Franjo Josip I. svečano otvorio Hrvatsko narodno kazalište u Zagrebu, bio je uhićen. Spriječen studirati u Zagrebu i Dvojnoj Monarhiji, studirao je u Parizu, od 1897. do 1899. godine. Marija Dvořák, odupirući se obiteljskom protivljenju da se veže za Stjepana Radića, udala se za njega u Pragu 1898. godine. ${ }^{1}$

Vidi sjećanja Marije Radić: Marija RADIĆ, Uspomene iz života na moga blagopokojnoga supruga Stjepana Radića, (ur. Maja MARIČIĆ i Iva GRUDEN ZDUNIĆ), http://marijaradic.pondi.hr/marija_radic_uspomene_web.pdf. 


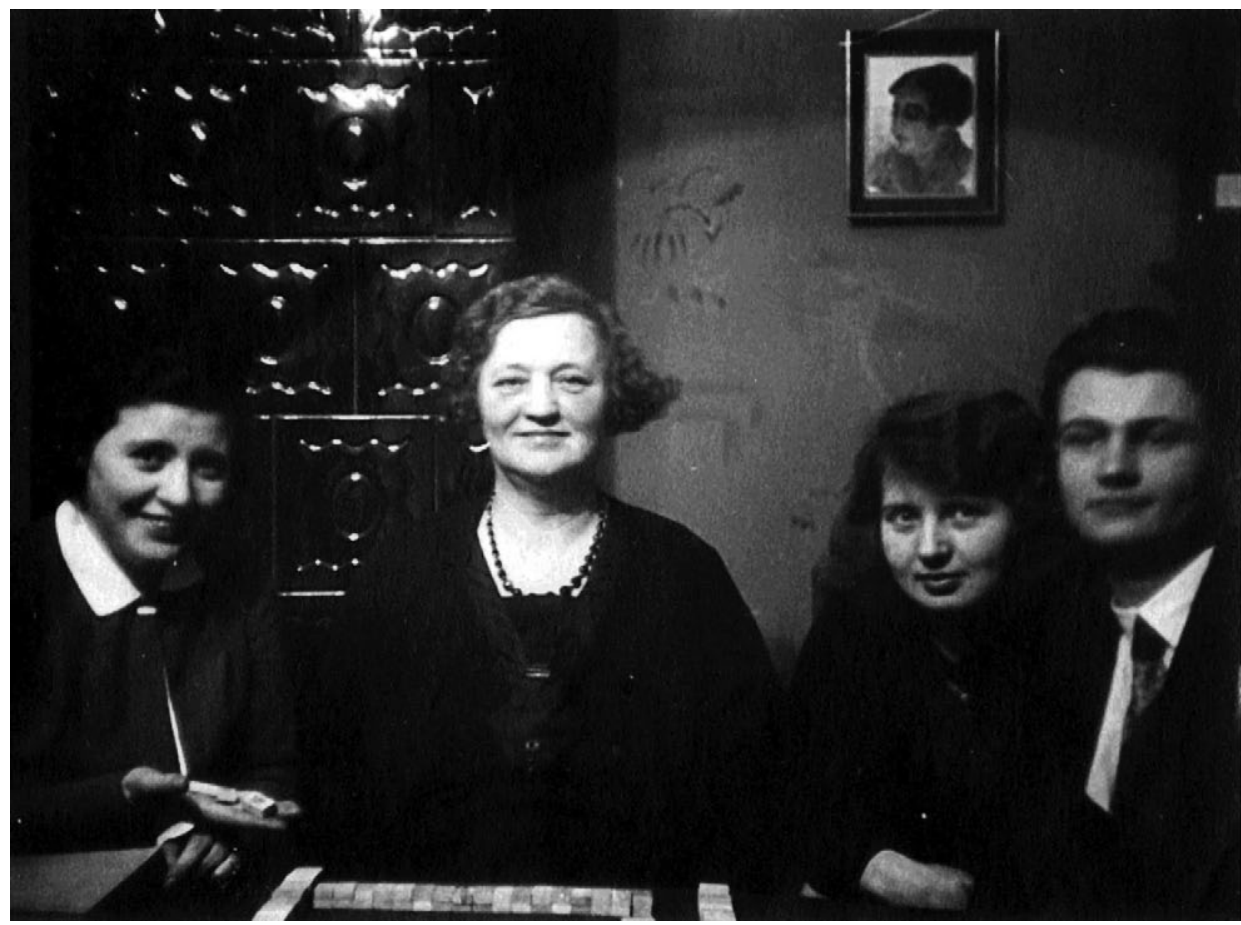

Slika 1. Marija Radić (u sredini) sa kćerkom Mirom (desno od Marije) i sinom Branislavom

Bila mu je, sve do njegove smrti, najbliža intelektualna i politička suradnica, o čemu svjedoči njihova opsežna prepiska, objavljena 1970-ih godina. ${ }^{2}$ Prepisivala je i ujedno sređivala njegove studentske bilješke s pariške Slobodne škole političkih znanosti, a nakon osnutka Hrvatske pučke seljačke stranke (HPSS) 1904. godine njihova se intelektualna, ali i politička suradnja intenzivirala. Osnovala je i kao predsjednica organizirala rad „ženske organizacije HSS-a” (od 1927.) i gospojinske zadruge Hrvatsko srce (od 1936.). ${ }^{3}$ Odbor ženskih grana HSS-a uz svoj politički program razvio je karitativnu, socijalnu i prosvjetnu djelatnost u svim izbornim kotarima i u gradu i na selu.

Ciljevi njezinog društvenog i političkog angažmana bila su jednaka prava žena u javnom životu, zapošljavanju i obrazovanju, ne zanemarujući opće narodne interese, ponajprije demokratizaciju i federalizaciju Kraljevine Srba, Hrvata i Slovenaca odnosno, od 1929. godine, Kraljevine Jugoslavije. ${ }^{4} \mathrm{Uz}$ intelektualnu i političku djelatnost bila je i vlasnica zagrebačke Slavenske knjižare, još jednog važnog centra okupljanja pripadnika Hrvatske seljačke stranke. U knjižari je radila i njezina kćerka Mira, udana za potpredsjednika HSS-a Augusta Košutića, s kojim je imala dvije kćeri. Bračni par Radić nije se samo u javnosti zalagao za bolje životne uvjete žena, nego je i svojim kćerima Miri i Milici omogućio visoko obrazovanje. ${ }^{5}$ Primjerice, Mira se školovala u Pragu i Zagrebu. Najprije je studirala tehniku

Vidi u: Bogdan KRIZMAN, Korespondencija Stjepana Radića, knj. 1-2, Zagreb 1972./1973.

List Hrvatica: časopis za ženu i dom redovito je donosio izvješća o radu ženske grane HSS-a i o radu Hrvatskog srca.

Vidi: Suzana LEČEK, „Dosada se samo polovica hrvatskog naroda borila'. Hrvatska seljačka stranka i žene (1918.1941.)”, Historijski zbornik, 59/2006., br. 1, 93.-130., ovdje 97.

Branka BOBAN, „Materinsko carstvo’. Zalaganje Stjepana Radića za žensko pravo glasa i ravnopravan položaj u društvu", Žene u Hrvatskoj. Ženska i kulturna povijest, (ur. Andrea Feldman), Zagreb 2004., 191.-209., ovdje 195. 
u Brnu. Studij nije završila zbog udaje. Vraća se u Zagreb i upisuje studij filozofije, ali je nakon očeve smrti prekinula i taj studij i posvetila se vođenju obiteljske knjižare.

Njezin otac smrtno je ranjen u atentatu zastupnika radikala Puniše Račića u Skupštini Kraljevine SHS u Beogradu 20. lipnja 1928. godine. Ubojstvo svoga supruga Marija Radić oštro je osudila izjavivši da je „borba u kojoj je poginuo Stjepan Radić više nego borba naroda hrvatskoga”, te da je to „borba zapadne kulture s tamnim i mračnim sramotama srednjega vijeka" ${ }^{6}$ Već su suvremenici smatrali kralja Aleksandra I. Karađorđevića odgovornim za atentat, dočim je Račić bio tek naručeni izvršitelj. ${ }^{7}$ Ni poslije smrti svoga supruga Marija Radić se nije prestala boriti za svoje ideale: već tri mjeseca nakon sahrane Stjepana Radića bila je na stranačkom skupu u Sunji, hrabreći žene da se i dalje bore i za prava žena kao i za narodna prava. ${ }^{8}$

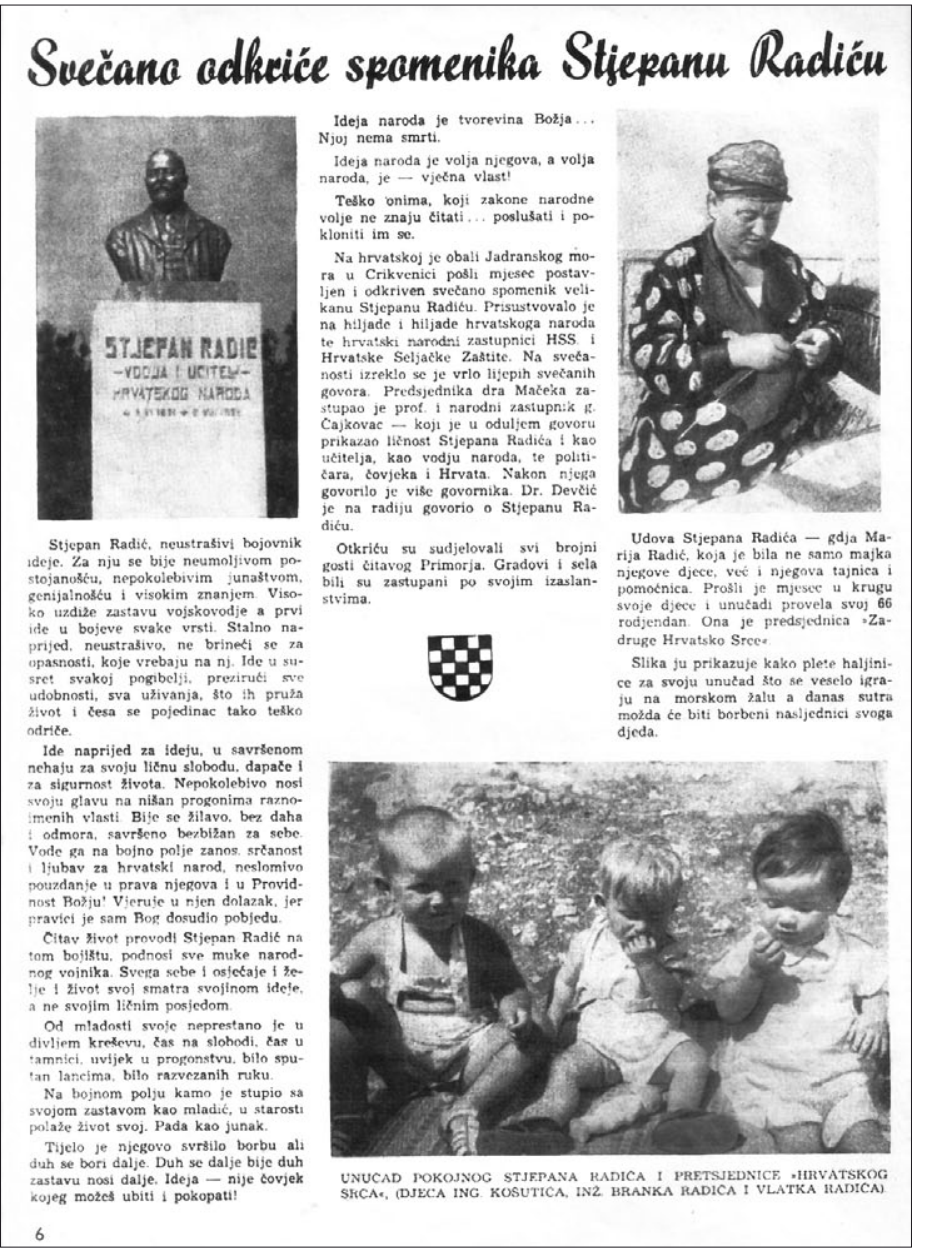

Slika 2. Obitelj pokojnog Stjepana Radića kao uzor ljudskih i obiteljskih vrijednosti članovima Hrvatske seljačke stranke

(„Svečano odkriće spomenika Stjepanu Radiću”, Hrvatica, br. 9, 9. rujna 1940.)

\footnotetext{
Marijan LIPOVAC, „Marija Radić - prva hrvatska političarka” (http://www.croatia.ch/ zanimljivosti /091113.php). Vidi članak Vladimira Radića: „20. lipnja 1928.”, Novi list (Zagreb), br. 52, 20. 6. 1941., 10.

8 S. LEČEK, „Dosada se samo polovica hrvatskog naroda borila”, 97.
} 


\section{Optužbe komunista o djelovanju Marije Radić i Mire Košutić za vrijeme NDH}

O djelovanju Marije Radić i Mire Košutić za vrijeme Drugog svjetskog rata u Nezavisnoj Državi Hrvatskoj još nema temeljitih istraživanja. Nasuprot tome, djelatnost HSS-a, zabranjenog u to doba, predmet je važnih historiografskih istraživanja. ${ }^{9}$ Povijesni kontekst ovog razdoblja u povijesti HSS-a obilježio je Vladko Maček, nasljednik Stjepana Radića, pozivajući hrvatski narod i pristaše HSS-a „na lojalan stav prema novoj vlasti.”"10 Bilo je to učinjeno nakon što je kasniji ministar hrvatskog domobranstva Slavko Kvaternik 10. travnja 1941. proglasio na radiju uspostavu Nezavisne Države Hrvatske, koja je bila njemačko-talijanska marionetska država pod vodstvom ustaškog „poglavnika” dr. Ante Pavelića. Prema mišljenju Mire Košutić Maček je to naredio „dobronamjerno sa željom da se spriječi strahovita krvoprolića do kojih bi svakako došlo davanjem besmislenog otpora okupatoru". ${ }^{11}$ Potpredsjednik HSS-a August Košutić već je 1930-ih održavao kontakte s Pavelićem, a u NDH je vodio pregovore o poziciji i mogućnostima djelovanja HSS-a na političkoj sceni. Ne uspijevši se nagoditi s ustašama, pokušao je pregovarati s partizanima, no ponovno bez uspjeha. Partizani su ga čak nakon neuspješnih pregovora internirali. Vodeći čovjek Komunističke partije Hrvatske Andrija Hebrang to je hapšenje opravdao Košutićevom zavjerom s Pavelićem i Mačekom o stvaranju zajedničke vlade. Koministi su Košutića tek u rujnu 1946. pustili iz zatvora.

U svrhu boljeg razumijevanja uloge Marije Radić i Mire Košutić za vrijeme Drugog svjetskog rata treba naglasiti da su zbog zabrane svih kulturno-političkih organizacija, kao i stranaka, ne baš malobrojni pripadnici HSS-a pristupili ustaškom pokretu. ${ }^{12} \mathrm{In}$ tegraciju u ustaški režim pripadnika i pripadnica Hrvatske seljačke stranke, najjače hrvatske stranke u međuratnom periodu, ustaše su propagadistički posebno naglašavali, a prisilno izjednačavanje predstavljao se kao tobožnja politička složnost svih Hrvata. ${ }^{13}$ Objavljivala su se imena predstavnica ženskih organizacija HSS-a koje su potpisale pristupanje ustaškom pokretu, $s$ ciljem da se demonstrira i potvrdi njihova nova politička orijentacija. ${ }^{14}$ Citirali su se govori predstojnice ženskih organizacija HSS-a Olge Barić u kojima je jamčila Paveliću u ime svih 6.000 organiziranih članica vjernost prema ustaškom pokretu i ustaškoj državi. To svjedoči njezin govor objavljen u Hrvatskom narodu:

\footnotetext{
Zdenko RADELIĆ, Hrvatska seljačka stranka 1941.-1950., Zagreb 1996. Vidi i: Ivo BANAC, With Stalin against Tito. Cominformist Splits in Yugoslav Communism, New York 1988.

10 Hrvatski državni arhiv, Zagreb, Služba državne sigurnosti republičkog sekretarijata za unutrašnje poslove Socijalističke Republike Hrvatske (SDS RSUP SRH), 1561/1945, 010.37, Nastavak zapisnika saslušavanja Mire Košutić dne 22. 1. 1945.

11 Hrvatski državni arhiv, SDS RSUP SRH, 1561/1945, sig. 010.37, Nastavak zapisnika saslušavanja Mire Košutić dne 22. 1.1945.

12 Vidi: Martina BITUNJAC, „Velike su naše dužnosti prema narodu’: intelektualke u Ženskoj lozi hrvatskog ustaškog pokreta", Intelektualci i rat 1939.-1947. Zbornik radova s medunarodnog skupa Desničini susreti 2011., (ur. Drago Roksandić i Ivana Cvijović Javorina), Zagreb 2012., 243.-253., ovdje 246. Lijevo krilo HSS-a kao i protivnici ustaške politike ujedinili su se s partizanskim pokretom. Vidi: Zdenko RADELIĆ, „Narodni glas - glas oporbe”, Časopis za suvremenu povijest, 26/1994., br. 2, 299.-315., ovdje 300.

13 Vidi primjerice: „Organizacije bivše HSS pristupaju u Ustaški pokret”, Hrvatski narod (Zagreb), br. 189, 22. 8. 1941., 5.

14 „Predstavnice ženskih organizacija bivše HSS koje su podpisale izjavu o pristupanju hrvatskom ustaškom pokretu”, Hrvatski narod (Zagreb), br. 192, 25. 8. 1941., 4.
} 
Mi žene, koje sačinjavamo brojnu polovicu hrvatskoga naroda, bile smo u b. HSS vjerne nauci vođe i učitelja Stjepana Radića. Na tisuće organiziranih Hrvatica iz svih družtvenih slojeva, okupljale smo se u našim ženskim granama, da vršimo dužnost prema domovini, koju su nam namijenili veliki Vodje Ante Starčević i Stjepan Radić. (...) Poglavniče! Naša domovina je slobodna Nezavisna Država Hrvatska. Njezino ostvarenje je Vaše djelo. ${ }^{15}$

Reakcija Marije Radić na pristupanje HSS-a odnosno ženske organizacije ustaškom pokretu nije poznata. Ako je u travnju 1941. - kao i većina Hrvata - pozitivno reagirala na uspostavu Nezavisne Države Hrvatske, bilo je to zato što je time bila srušena centralistička Kraljevina Jugoslavija. Ona se i sama sa svojim suprugom borila da ostvari autonomnu Hrvatsku kao jedinicu u (kon)federativnoj Jugoslaviji. Svoj otpor ustaškome rasističkom režimu koji kooperira s njemačkim nacionalsocijalistima i talijanskim fašistima iskazala je, po Lipovcu, kad je nakon ulaska Wehrmachta u Zagreb u izlog svoje knjižare postavila knjigu Petra Zrinskog u kojoj se nalazio stih Viruj Nimcu kako suncu zimsku. ${ }^{16}$

$S$ druge strane je kao žena hrvatskoga uglednog političara, preminulog nakon političkog atentata u kraljevinskoj Skupštini, bila ustašama svakako propagandistički od velike koristi. Prema novinama Hrvatski narod sudjelovala je, zajedno sa članovima svoje obitelji, kao počasni gost na „danu hrvatskih mučenika” održanom 20 . lipnja, ${ }^{17}$ u čast svim „mučenicima za slobodu Hrvatske”. Na toj svečanoj zadušnici bile su prisutne obitelji Soldin i Hranilović, čiji su muški članovi ubijeni za vrijeme diktature, te svi glavni funkcioneri i ministri ustaške vlasti. ${ }^{18}$

Isto tako, Marija Radić s kćerkom Mirom Košutić i sinom Vladimirom imala je reprezentativnu ulogu u krugu ustaških funkcionera, ministara i ustaške bojne na obljetnici smrti Stjepana Radića, na kojoj je Pavelić u svoje ime dao postaviti vijenac. ${ }^{19}$ Nasuprot ugledne uloge Stjepana Radića, ustaše nisu, odnosno nisu mogli, stilizirati i njegovu suprugu u „ustašku junakinju” kao što je to bio običaj sa ženama iz prošlosti ili suvremenim ženama i majkama poznatih hrvatskih političara. Kao prvo, ona se kao strankinja t. j. Čehinja, aktivistica za ženska prava i politički orijentirana HSS-ovka ipak nije uklapala u shemu ustaške rasističke ženske politike. Kao drugo, ona sama nije dopuštala da postane ustaškom marionetom, a ustaški režim ubrzao joj je postao nepodnošljiv.

Komunistima je pak bila trn u oku jer su njezin stav prema NDH definirali nedistanciranim. U poslijeratnim policijskim dokumentima kritizira se njezina reakcija prema ustašama nakon osnivanja Nezavisne Države Hrvatske. Kao dokaz su se naveli njezin osobni posjet ustaškom vođi Ante Paveliću odmah nakon preuzimanja vlasti, kao i primanje počasne mirovine za vrijeme NDH. Komunisti su u svojim glasilima optuživali i druge članove obitelji Radić za suradnju s ustaškim režimom zbog njihove aktivnosti u novinarstvu. Nakon sloma NDH bili su internirani i/ili su dobili trajnu zabranu bavljenja publicistikom. ${ }^{20}$

\footnotetext{
„Danas su hrvatski ideali u prvom stupnju podpuno ostvareni”, Hrvatski narod (Zagreb), br. 192, 25. 8. $1941 ., 1$.

16 Marijan LIPOVAC, „Marija Radić - prva hrvatska političarka” (http://www.croatia.ch/ zanimljivosti/ 091113.php).

17 Zadušnice su se držale od 1928. čak i za vrijeme diktature, radi čega su žene iz obitelji Radić znale biti privođene u policiju, tako da je ovo samo ustaško korištenje starog „nacionalnog dana”.

18 „Dan hrvatskih mučenika. Grad Zagreb, zavijen u crninu, odao je dostojnu počast svim mučenicima za slobodu Hrvatske“, Hrvatski narod (Zagreb), br. 127, 21. 6. 1941., 1.

19 „Zagreb na tužnu obljetnicu”, Hrvatski narod (Zagreb), br. 176, 9. 8. 1941., 1.

20 Z. RADELIĆ, Hrvatska seljačka stranka, 78.
} 
Na policijskom saslušanju 1948. godine, reflektirajući ratne godine, Radićeva kćerka Mira pokušala je ublažiti averziju komunista prema njezinoj obitelji riječima:

Dolazak narodno oslobodilačke vojske očekivali smo svi jednodušno s oduševljenjem. $\mathrm{Ne}$ samo što je to bilo spojeno sa svršetkom rata, nego što je tim dolaskom i preuzećem vlasti bila zauvijek skinuta s hrvatskog naroda teška mora ustaštva i okupacije. Činjenica da se je s prvim odredima te vojske vratio samo moj brat - ing. Branislav Radić - a ne moj muž koji su zajedno otišli na oslobodjeni teritorij strahovito me je rastužila, ali sam vjerovala, da će se to sve popraviti i razjasniti. ${ }^{21}$

Mira Košutić je kao glasnogovornica svoga uhapšenog muža igrala vrlo važnu ulogu među pristašama HSS-a. U ovoj izjavi može se uočiti njezina razočaranost ustaškom državom, ali i novom vlašću koja je njezinog supruga toliko dugo držala u zatvoru. Već je tada mogla shvatiti da se u Titovoj Jugoslaviji njezina stranka neće moći obnoviti.

\section{Posljeratna politička aktivnost}

Marija Radić i Mira Košutić su se kratko nakon rata nalazile na „političkom vrhu” stranke: predvodile su opozicijsku frakciju i bile ravnopravne u društvu njezinih muških predvodnika. Bez obzira na to što HSS nakon rata nije imao velike mogućnosti da se politički afirmira, Marija Radić i Mira Košutić, kao i uži krug HSS-ovca, nisu se dali obeshrabriti, nego su, nakon što je izašao zakon o štampi i time prvi oporbeni list u Jugoslaviji - beogradska Republika - objavili glasilo pod imenom Narodni glas čovječnosti, pravice i slobode. Glavni urednik bio je Ivan Bernardić, jedan od šefova HSS-ove omladine. Prvi i zadnji broj lista izašao je 20. listopada 1945. u 50.000 primjeraka. Nakon što je bio brzo rasprodan, grupa HSS-ovca ih je ponovno dala tiskati u istoj količini. Uvodni dio Narodnog glasa pod naslovom Naš prvi broj sastavila je Marija Radić ističući volju da u tradiciji Stjepana Radića opstane „duševna veza” s hrvatskim narodom. Otvoreno je kritizirala komuniste, a pojedinačno je navela novine Vjesnik, Narodni list i Borbu, koje po njezinom stavu nisu hrvatske, nego tuđe:

To je bio razlog, da smo se odlučili, da izdajemo za sada barem jedan tjednik, kad nam sve te komunističke novine toliko naglasuju slobodu, da vidimo, kako će to izgledati u praksi. Znamo doduše unapred, da će nas nazvati za svaku kritiku ovoga režima, dotično za svako zloporabu vlasti, na koju ćemo upozoriti, reakcionarcima, ali to nam neće smetati, da nastavimo naš rad u pravom duhu Stjepana Radića i u istini, jer se jedino kritikom i otvorenošću može postići, da se po koje zlo, kojega ima puno i na sve strane, barem umanji, ako se već i podpuno ne odstrani. ${ }^{22}$

U nepotpisanom članku Zašto ne idemo na izbore?, ${ }^{23}$ koji je napisala Mira Košutić, poziva se narod na bojkot izbora za Ustavotvornu skupštinu 11. studenoga 1945. zato što u fazi nastajanja socijalističke Jugoslavije nisu bili poštivani sporazumi između vođe Narodnooslo-

\footnotetext{
21 Hrvatski državni arhiv, SDS RSUP SRH, 1561/1945, sig. 010.37, Izjava Mire Košutić, dne 21.1.1948.

22 „Naš prvi broj”, Narodni glas čovječnosti, pravice i slobode (Zagreb), br. 1, 20. 10. 1945., 1. Članak spominje i Z. RADELIĆ, Hrvatska seljačka stranka, 79.
} 
bodilačkog pokreta Josipa Broza Tita i bana Banovine Hrvatske Ivana Šubašića, potpisani na Visu 1944., odnosno u Beogradu početkom 1945. godine, nego je Komunistička partija u Privremenoj skupštini Jugoslavije stekla dominantnu poziciju i otežavala HSS-u, kao i drugim strankama, pripreme za izbore. ${ }^{24}$ Zbog apsolutne kontrole izborne kampanje HSS faktično i nije mogao konkurirati KPJ. Narodnooslobodilačkom pokretu u članku se priznalo oslobođenje od fašističke i nacionalsocijalističke sile, ali su se postupci Komunističke partije na izborima osuđivali kao nedemokratski i nepošteni. ${ }^{25}$

Glavni funkcioneri te stranke nisu bili pušteni iz zatvora, a Vladko Maček, u inozemstvu od svibnja 1945. godine, izbjegavao je suradnju s komunistima i protivio se sudjelovanju na izborima jer bi se time prizvao legitimitet nove vlasti. ${ }^{26} \mathrm{No}$, nasuprot tome postojale su ideje da se na čelo kandidatske liste postavi Mariju Radić, do čega ipak nije došlo.

Komunistička vlast je odmah reagirala na oporbeni tisak i naredila privremenu zabranu širenja lista s ocjenom da Narodni glas „širi laži i klevete, izaziva nacionalnu mržnju i propagira rad neprijatelja”. ${ }^{27}$ Zabrana prodaje prvoga broja nije demotivirala Mariju Radić i njezine suradnike, jer su se, kako opisuje Mira Košutić na saslušanju 1948. godine, držali donesenog zakona o štampi. Do izdavanja drugog broja Narodnog glasa ipak nije došlo. Službena verzija glasila je da su sami radnici odbili tiskanje „reakcionarnog” lista jer se u njemu „piše protiv naroda i stečevina NOB-a". ${ }^{28}$

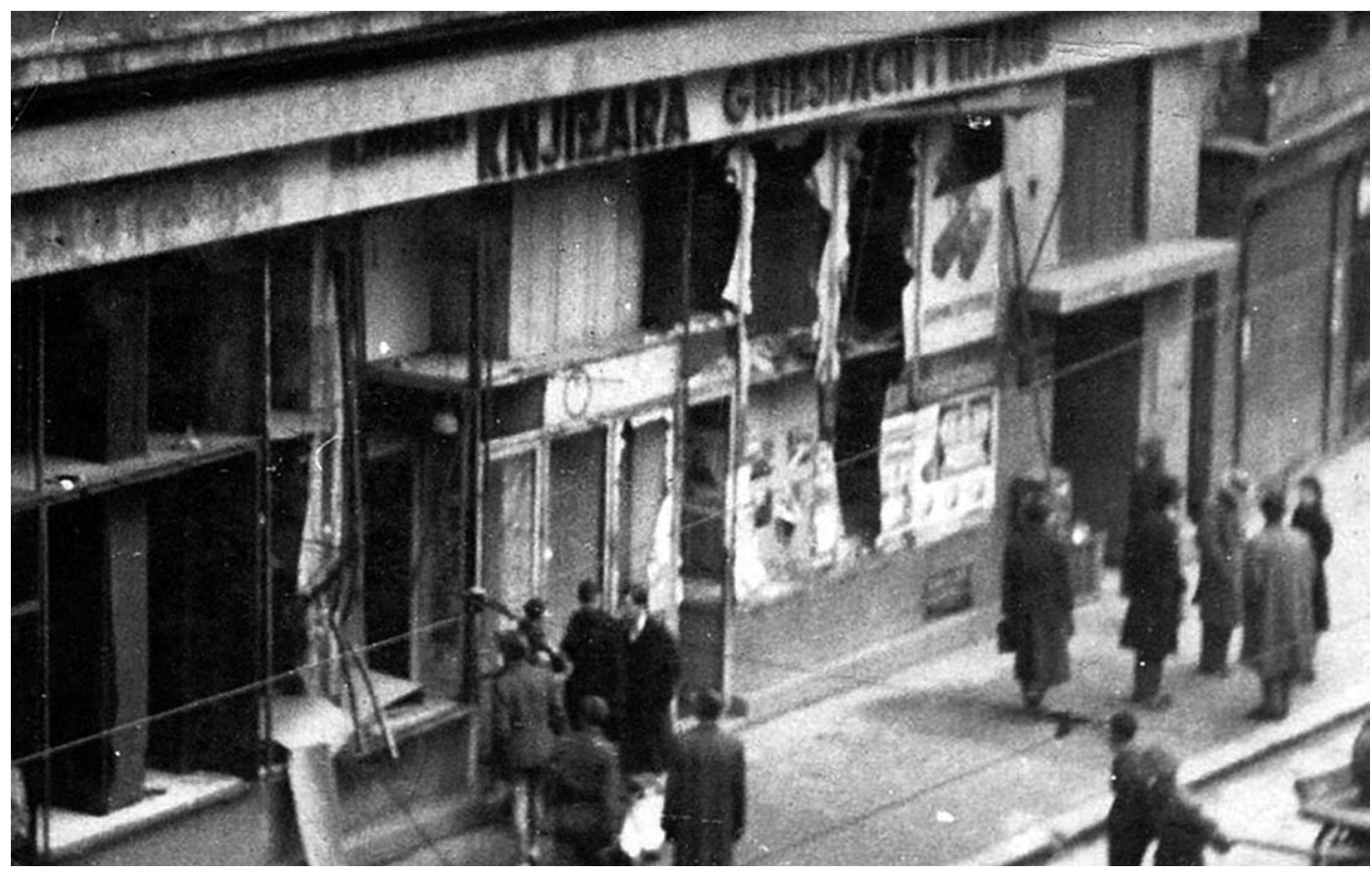

Slika 3. Knjižara Marije Radić nakon eksplozije podmetnute bombe 12. studenog 1945.

23 Vidi: Z. RADELIĆ, Hrvatska seljačka stranka, 79.-80.

24 Isto, 84.-92.

25 „Zašto ne idemo na izbore?”, Narodni glas čovječnosti, pravice i slobode (Zagreb), br. 1, 20. 10. 1945., 1-2., ovdje 1.

26 Z. RADELIĆ, „Narodni glas - glas oporbe”, 301.

27 Božidar NOVAK, Hrvatsko novinarstvo u 20. stoljeću, Zagreb 2005., 457.

28 Isto. 
Ubrzo nakon prestanka izdavanja lista bio je onemogućen svaki javni rad ove skupine HSS-ovca, ali nije se ostalo samo na tome. U kolovozu 1945. mladi komunist, točnije pristaše Ujedinjenog saveza antifašističke omladine Hrvatske (USAOH), demolirali su Slavensku knjižaru. Postavljeni eksploziv uništio je velik dio obiteljske imovine. Marija Radić bila je prisiljena iseliti se iz svoje vile u Hercegovačkoj ulici te je otišla živjeti k svojoj kćeri Miri. No, sudski postupak protiv nje nije pokrenut: ipak su joj slava i prestiž njezinog supruga Stjepana Radića, s kojim je do njegove smrti uporno radila na poboljšanju životnih uvjeta seljačkog naroda, osigurali zaštitu od komunističke represije.

\section{$\cos$}

\section{Marija Radić and Mira Košutić: intellectuals in a POLITICAL MISSION}

Marija Radić, nee Dvořák (1874-1954) and her daughter Mira (1901-1988) played significant roles in the cultural and political life of Croatia and Yugoslavia. As the wife of the leader of the Croatian Peasants' Party (HSS) Stjepan Radić, Marija Radić was the founder of the party's women's organizations and, like her husband, devoted to the cause of women's rights. After Stjepan Radić was assassinated by the radical Puniša Račić in 1928, Marija Radić was exalted by the NDH as the widow of an alleged Ustashe martyr. Her daughter, Mira, whose married name was Košutić, left her studies after her father's death to take over the family bookstore. During the war, between 1941 and 1945, she and her husband August Košutić, who was the party's vice-president, went on to illegally prepare the post-war reconstruction of the party. However, their efforts were futile. Mira Košutić was arrested and members of the Zagreb branch of SKOJ destroyed her Zagreb bookstore. This article provides an overview of the political activity and culture of these two women, who are prominent figures the interwar period in Croatia.

Keywords: Marija Radić, Mira Košutić, Croatian Peasant’s Party

\section{$\cos$}

\section{Literatura}

Ivo BANAC, With Stalin against Tito. Cominformist Splits in Yugoslav Communism, New York 1988.

Martina BITUNJAC, „Velike su naše dužnosti prema narodu': intelektualke u Ženskoj lozi hrvatskog ustaškog pokreta", Intelektualci i rat 1939.-1947. Zbornik radova s međunarodnog skupa Desničini susreti 2011., (ur. Drago Roksandić i Ivana Cvijović Javorina), Zagreb 2012., 243.-253.

Branka BOBAN, „Materinsko carstvo’. Zalaganje Stjepana Radića za žensko pravo glasa i ravnopravan položaj u društvu“, Žene u Hrvatskoj. Ženska i kulturna povijest, (ur. Andrea Feldman), Zagreb 2004., 191.-209.

Bogdan KRIZMAN, Korespondencija Stjepana Radića, knj. 1-2, Zagreb 1972./1973. 
Suzana LEČEK, „'Dosada se samo polovica hrvatskog naroda borila’. Hrvatska seljačka stranka i žene (1918.-1941.)", Historijski zbornik, 59/2006., br. 1, 93.-130.

Suzana LEČEK - Željko DUGAC, „Majke za zdravlje djece: zdravstveno prosvjetna kampanja Seljačke sloge (1939.-1941.)”, Časopis za suvremenu povijest, 38/2006., br. 3, 983.-1005.

Marijan LIPOVAC, „Marija Radić - prva hrvatska političarka” (http://www.croatia.ch/zanimljivosti/091113.php).

Mara MATOČEC, „Hrvatice i pravo glasa”, Hrvatica. Časopis za ženu i dom, 1/1939., br. 11, 1.

Božidar NOVAK, Hrvatsko novinarstvo u 20. stoljeću, Zagreb 2005.

Zdenko RADELIĆ, Hrvatska Seljačka Stranka 1941.-1950., Zagreb 1996.

Zdenko RADELIĆ, „Narodni glas - glas oporbe”, Časopis za suvremenu povijest, 26/1994., br. 2, 299.-315.

Marija RADIĆ, Uspomene iz života na moga blagopokojnoga supruga Stjepana Radića, (ur. Maja Maričić i Iva Gruden Zdunić), http://marijaradic.pondi.hr/marija_radic_uspomene_web.pdf.

\section{Novine}

Narodni glas čovječnosti, pravice i slobode (Zagreb)

Hrvatski narod. Glasilo hrvatskog ustaškog pokreta (Zagreb)

\section{Arhivski fond}

Hrvatski državni arhiv, Zagreb, Služba državne sigurnosti republičkog sekretarijata za unutrašnje poslove Socijalističke Republike Hrvatske (SDS RSUP SRH), 1561/1945, sig. 01037. 